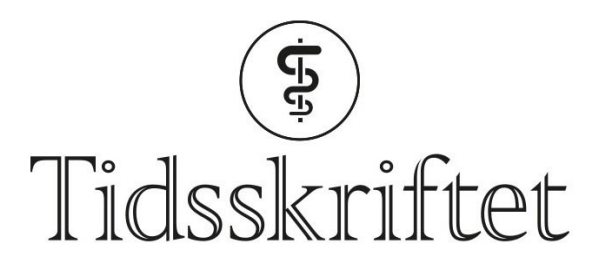

DEN NORSKE LEGEFORENING

\title{
Legen og kvakksalveren
}

TIDLIGERE I TIDSSKRIFTET

SYNNE LOFSTAD

E-post: synne.lofstad@hotmail.com

Redaksjonssjef i Æsculap

Ole Jacob Broch, overlege i indremedisin ved Haukeland sykehus, ga i 1954 ut boka Lege eller kvaksalver. I Æsculap kommer han med en klar formaning til legestanden om å kjenne sine grunnleggende prinsipper, medisinsk forskning og samfunnets velferd. Som han sier: «Toleranse er en utmerket egenskap, men iblandt er den lunkenhetens hodepute» (Æsculap 1955; 35: 22-4).

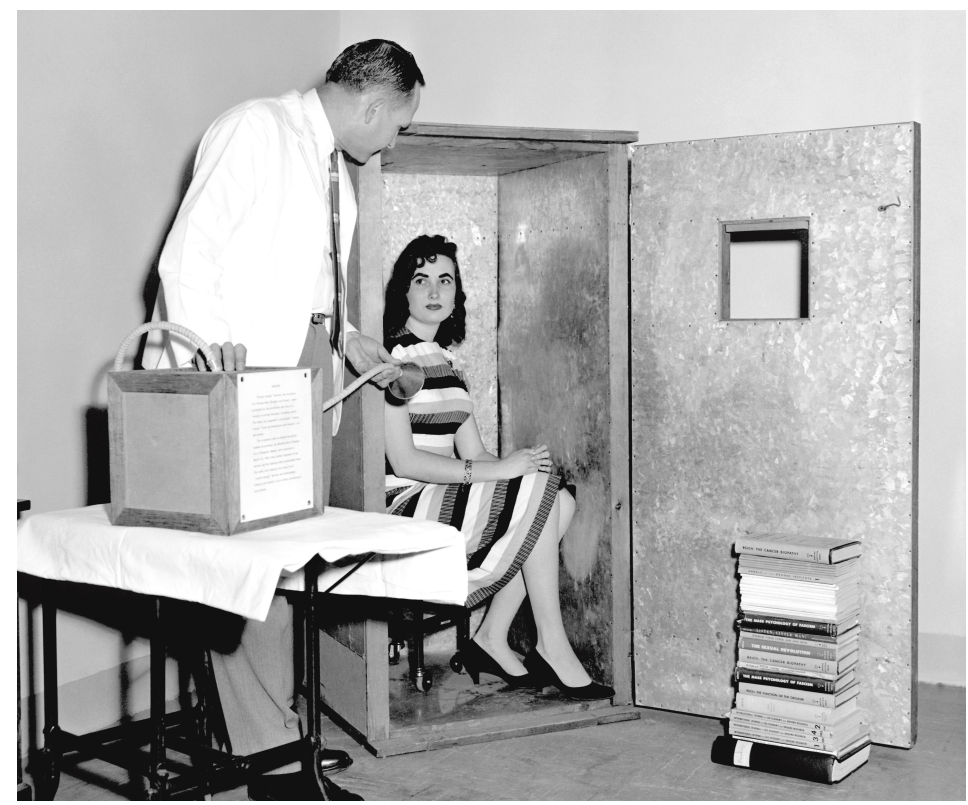

Demonstrasjon av en Orgone akkumulator. Orgone er ifølge den østerrikske psykoanalytikeren Wilhelm Reich en universell livskraft. I 1954 beordret FDA ødeleggelse av alle akkumulatorer og all litteratur som omtaler dem. Reich, som bodde i USA, ble senere fengslet for å ha krenket forbudet. Illustrasjonsfoto: Science Photo Library / NTB Scanpix

\section{Fornuft kontra mystikk i legekunsten.}

\section{AV OLE JACOB BROCH.}

(...) De direkte skadevirkninger av kvaksalvernes virksomhet er det vanskelig å få full oversikt over. Deres vesentlige klientell er sikkert nevrotikerne. Legene har i de fleste tilfelle fått sine sjanser først og vil sikkert ikke personlig beklage å bli avlastet for en tung terapeutisk byrde. Imidlertid blir det sikkert ikke få pasienter som ved kvaksalvernes 
inngripen forspiller det rette tidspunkt for en rasjonell og effektiv terapi av sin sykdom.

Kvaksalverproblemets alvorligste side er imidlertid ikke at en og annen pasient blir alvorlig syk eller dør p. g. a. at de ikke får sakkyndig behandling. Legene har jo endel på samvittigheten i den retning. Alvorligere er den undergravning av fornuft og rasjonell tankegang som kvaksalveriet representerer. (...)

Legene er vel heller ikke selv helt uten skyld

Legene er vel heller ikke selv helt uten skyld. De har hatt det for travelt med egne problemer til å ta seg av dette spørsmål. Enkelte har dessuten vist en holdning som jeg tror er meget skadelig. Jeg tenker ikke på det personlige samarbeid med kvaksalvere som er tydelig forbudt etter Legeforeningens kollegiale lover. Det spiller sikkert en helt uvesentlig rolle. Derimot ser en iblant at leger stiller seg forståelsesfulle og delvis gir sin tilslutning til forskjellige filosofiske helsesystemer som bryter med det naturvitenskapelige grunnlag som legegjerningen bygger sin eksistens på. Mange av disse helsesystemene har en temmelig stor utbredelse i befolkningen. Det drives en sterk og hemningsløs propaganda for det syn at alle våre sykdommer er en følge av vår sivilisasjon og unaturlige livsførsel. Veien til full helse med frihet for alle sykdommer fører «tilbake til naturen». Ingen får vite hva som menes med dette. Rent praktisk blir det som regel tillempet ved å spise råkost og gjennomføre det rituale som profeten forkynner. (...)

Ikke helt sjelden hender det at kolleger også forviller seg inn i denne dype jungel av merkelige påstander og hypoteser som det aldri gis noen begrunnelse for. Det skal vises toleranse og frisinn, heter det. Og har ikke store medisinske nyheter også tidligere sprunget fram fra folkedypet og først senere blitt akseptert av legevitenskapen? - Var det ikke en gammel kone som praktiserte solbehandling på Ekeberg lenge før D-vitaminet ble oppdaget?, og forstrakk ikke også en enkelt kone Withering i England med oppskrift på Digitalis? Kneippbrødet ble introdusert av en munk, og det kan for den saks skyld sikkert også påvises at en eller annen from enke satt og slappet av hele dagen hundrer av år før Seyffarth skrev sin bok.

Det glemmes så lett at folkemedisinen vesentlig er bygget på tro og mystikk og ikke på iakttagelser, at likt og ulikt ble behandlet. Først systematiske undersøkelser har gitt oss et rasjonelt grunnlag og vist om en metode er verdifull og hvordan den skal brukes. Genier kan nok fremdeles miskjennes, men heldigvis er det som regel meget lett med sikkerhet å erkjenne det rene tøv. Helseprofetenes lære har aldri så vidt jeg har sett, appellert til logikk og fornuft. Flere av dem hevder endog at en naturvitenskapelig vurdering er uten verdi. Derfor nytter det lite at det meste av deres påstander er motbeviste, argumenter og fornuft preller av mot blind tro.

Kvaksalveriet er i virkeligheten et angrep mot vår sosiale levestandard

Ethvert fenomen som undergraver mennesketanken og sunn fornuft tjener en sosial reaksjon. Kvaksalveriet er i virkeligheten et angrep mot vår sosiale levestandard. Mest tydelig kommer dette fram i de forskjellige helsesystemer. (...) Parolen «Tilbake til naturen» betyr i virkeligheten tilbake fra den tekniske utvikling til en lavere levestandard med derav følgende sykelighet og dødelighet.

Det kan være vanskelig å få lekfolk til å erkjenne at en vitenskapelig forskning er eneste grunnlag for medisinsk framgang når leger i misforstått toleranse er villige til å rekke en hånd til kvasivitenskapelig tøv. En kraftig reaksjon mot den slags fenomener må heller bli karakterisert som sneversyn og intoleranse. For å verne om sannhet, fornuft og rasjonell tankegang må endog hensynet til toleransen vike. Toleranse er en utmerket egenskap, men iblandt er den lunkenhetens hodepute.

(...) Vi må stille oss til tjeneste for all opplysning som tar sikte på å redusere kvaksalveriet og gjøre den medisinske terapi lettere tilgjengelig for befolkningen.

Vi må innrømme at vi ikke alltid er så flinke til å hjelpe selv 
Vi viser toleranse og forståelse overfor våre pasienter når de søker kvaksalvere, fordi vi må innrømme at vi ikke alltid er så flinke til å hjelpe selv. Men, la det ikke være tvil om vår prinsipielle holdning og la oss også ta klar avstand fra kolleger som uansett motivene slutter opp om de kvasivitenskapelige helseforførere. De forråder i virkeligheten derved de ukrenkelige prinsipper som er grunnleggende for legeyrket, medisinsk forskning og samfunnets velferd.

Hvis vi viser klare linjer her, vil det være mindre grunn til å øde sine krefter med å kaste stein på en tilfeldig kiropraktor, homøopat eller helbredende pinsevenn.

Publisert: 30. mars 2020. Tidsskr Nor Legeforen. DOI: 10.4045/tidsskr.20.0136 (C) Tidsskrift for Den norske legeforening 2020. Lastet ned fra tidsskriftet.no 